\title{
Pengaruh Derajat Desentralisasi Fiskal terhadap Pertumbuhan Ekonomi di Wilayah Barat Selatan Provinsi Aceh Periode Tahun 2011-2019
}

\author{
Alisman ${ }^{1}$, Dedi Sufriadi ${ }^{2}$ \\ ${ }^{1}$ Fakultas Ekonomi, Universitas Teuku Umar, Aceh Barat, Indonesia. \\ ${ }^{2}$ FKIP Ekonomi, Universitas Serambi Mekkah, Banda Aceh, Indonesia.
}

\begin{abstract}
Abstrak. Tujuan dari penelitian ini untuk mengetabui pengarub derajat desentralisasi fiskal terhadap pertumbuban ekonomi di Wilayah Barat Selatan Provinsi Aceh periode tahun 2011-2019. Adapun data yang yang digunkan adalah data sekunder yang diperoleh dari Badan Pusat Statistik. (BPS) provinsi dan kabupatenkabupaten/kota wilayah Barat Selatan Provinsi Aceh, dan juga dari instansi terkait yang mempunyai relevansi dengan pokok permasalahan penelitian ini. Penelitian ini menggunakan model analisis regresi linear sederhana. Variabel yang digunakan adalah pertumbuhan ekonomi (variabel terikat) dan desentralisasi fiskal (variabel bebas). Hasil penelitian menunjukkan bahwa derajat desentralisasi fiskal di wilayah Barat Selatan Aceh berpengaruh positif terbadap pertumbuban ekonomi di Barat Selatan Aceh. Diharapkan kepada Pemerintah Kabupaten/Kota Barat Selatan Provinsi Aceh supaya dapat meningkatkan pertumbuban ekonomi, dan menggali sektor-sektor ekonomi produktif dan potensial yang dapat memberi pengarub terbadap derajat desentralisasi fiskal di Wilayah Barat Selatan Provinsi Aceh.
\end{abstract}

Kata kunci: Pertumbuban Ekonomi, Desentralisasi Fiskal.

\begin{abstract}
The purpose of this study was to determine the effect of the degree of fiscal decentralization on economic growth in the South West Region of Aceh Province for the period 2011-2019. The data used are secondary data obtained from the Provincial Statistics Agency (BPS) and districts/cities in the South West region of Aceh Province, as well as from related agencies that have relevance to the subject matter of this research. This study uses a simple linear regression analysis model. The variables used are economic growth (dependent variable) and fiscal decentralization (independent variable). The results showed that the degree of fiscal decentralization in the South West Aceh region had a positive effect on economic growth in the South West Aceh. It is hoped that the District I City Governments of the South West of Aceh Province can increase economic growth, and explore productive and potential economic sectors that can influence the degree of fiscal decentralization in the South West Region of Aceh Province.
\end{abstract}

Keywords: Economic Growth, Fiscal Decentralization. 


\section{Pendahuluan}

Kebijakan desentralisasi fiskal di Indonesia yang dimulai dari tahun 2001 merupakan sebuah tanjakan dari awalnya pemerintah yang bersifat sentralisasi manjadi pemerintah yang desentralisasi. Desentralisasi merupakan alat atau intrumen yang harus digunakan untuk mewujudkan tata kelola pemerintahan yang efektif (Bangun, 2009), transparan dan akuntabel (Kusuma, 2016; Suriani, 2014). Desentralisasi fiskal otonomi daerah bertujuan untuk menciptakan kemandirian daerah. Pemerintah Daerah diharapkan mampu menggali dan mengoptimalkan potensi keuangan lokal-nya, khususnya pendapatan asli daerah (PAD), karena kebijakan ini diiringi perlimpahan kewenangan pemerintah pusat kepada pemerintah daerah sehingga dimungkinkan digali berbagai peluang sumber pendapatan daerah (lokal).

Pelaksanaan desentralisasi fiskal di Indonesia ditandai dengan proses pengalihan sumber keuangan dari pemerintah pusat ke pemerintah daerah dalam jumlah yang sangat signifikan yang diwujudkan dalam bentuk pemberian transfer pada daerah (Pasaribu, 2012; Kharisma, 2013) sesuai dengan amanat undang-undang Nomor 34 Tahun 2004 terkait Dana Perimbangan, Dana Otonomi Khusus dan penyesuaian serta dalam bentuk Pendapatan Asli Daerah (PAD). Salah satu bentuk tolak ukur untuk melihat kemampuan daerah dalam pelaksanaa otonomi daerah adalah dengan melihat seberapa besar kemampuan suatu daerah untuk menyelenggarakan otonomi daerah sesuai dengan undang-undang Nomor 32 Tahun 2004 tentang Pemerintah Daerah, Sumber Pendapatan Daerah salah satunya berasal dari Pendapatan Asli Daerah (PAD).

Kawasan Pantai Barat Selatan Provinsi Aceh merupakan wilayah yang berada di sepanjang pesisir laut, di mana kawasan tersebut terdiri dari 8 (delapan) kabupaten kota terdiri dari Kabupaten Aceh Jaya, Kabupaten Nagan Raya, Kabupaten Aceh Barat, Kabupaten Aceh Barat Daya, Kabupaten Aceh Selatan, Kota Madya Subulussalam, Kabupaten Aceh Singkil dan Kabupaten Sinabang. Semua
Kabupaten sudah menerapkan otonomi daerah melalui UU Nomor 32 Tahun 2004 dan UU Nomor 33 tahun 2004. Kekayaan potensi dan keunggulan yang dimiliki oleh wilayah Barat Selatan Aceh yang kaya akan Sumber Daya Alam menjadi pemasok atau penerimaan Pendapatan Daerah khususnya sebagai peningkatan Pendapatan Asli Daerah (PAD). Kekayaan alam tersebut merupakan salah satu kontribusi penerimaan Pendapatan Daerah dalam meningkatkan perekonomiannya (Sufriad, 2015). Tabel berikut memperlihatkan Pendapatan Asli Daerah di wilayah Barat Selatan Provinsi Aceh:

\section{Tabel 1.}

Realisasi Pendapatan Asli Daerah di Wilayah Barat Selatan Provinsi Aceh Tahun 20132019

\begin{tabular}{ccc}
\hline No & Tahun & PAD (RP) \\
\hline 1 & 2013 & $1.325 .435 .091 .289,19$ \\
2 & 2014 & $1.134 .104 .242 .954,23$ \\
3 & 2015 & $1.217 .566 .428 .915,54$ \\
4 & 2016 & $1.352 .653 .527 .681,65$ \\
5 & 2017 & $1.483 .931 .614 .230,86$ \\
6 & 2018 & $1.586 .549 .420 .655,00$ \\
7 & 2019 & $1.717 .827 .507 .204,78$ \\
\hline
\end{tabular}

Sumber; BPS Aceh, 2020

Berdasarkan tabel 1 dapat dijelaskan peneliti bahwa perkembangan PAD wilayah Barat Selatan Aceh, pada tahun 2013 jumlah PAD terus meningkat sebesar 1.325 trilyun rupiah, dan padat 2014 juga terjadi kenaikan yang sangat besar sejumlah 1.134 trilyun rupiah, kenaikan ini disebabkan dengan pajak kendaran yang meningkat. sedangkan pada tahun 2015 PAD di Barat Selatan Aceh terjadi penurunan sebesar 1.217 trilyun rupiah, dan pada Tahun 2016 PAD di Provinsi Aceh terjadi lagi kenaikan sebesar berjumlah 1.352 trilyun rupiah. Sedangkan perkembangan PDA wilayah Barat Selatan Aceh pada tahun 2019 lebih tinggi sebesar Rp1.717 trilyun rupiah bila dibandingkan dengan tahun sebelumnya 2018 yang hanya sebesar Rp. 1.586 trilyun rupiah.

Wilayah Barat Selatan Aceh dikenal dengan kaya akan sumber daya alam baik itu berupa tambang dan non tambang, potensi laut dan wisatanya. Oleh karena itu dapat kita pastikan bahwa pertumbuhan ekonomi juga pastinya akan ikut meningkat di karenakan kekayaan alam yang melimpah sehingga masyarakat Barat Selatan Aceh pada khususnya dan Aceh pada umumnya 
memiliki banyak peluang pekerjaan baik itu di Sektor Industri maupun Non Industri apalagi dengan adanya dana otonomi khusus (otsus) akan memberikan dampak positif terhadap perkembangan/pertumbuhan ekonomi kawasan Barat Selatan Aceh.

Tabel 2

Nilai Produk Domestik Regional Bruto atas Harga Konstan dan Tingkat Pertumbuhan Ekonomi Wilayah Barat Selatan Provinsi Aceh Tahun 2013-2019

\begin{tabular}{clc}
\hline Tahun & $\begin{array}{c}\text { PDRB (juta } \\
\text { rupiah) }\end{array}$ & $\begin{array}{c}\text { Pertumbuh } \\
\text { an (\%) }\end{array}$ \\
\hline 2013 & $94.290 .896 ., 20$ & 4.15 \\
2014 & $98.205 .891,50$ & 4.02 \\
2015 & $102.154,486,40$ & 4.28 \\
2016 & $106.522,864,80$ & 4.31 \\
2017 & $111.118 .991,70$ & 0.87 \\
2018 & $112.087 .732,21$ & 1.40 \\
2019 & $113.653 .217,90$ & 1.17 \\
\hline Sumber: BPS Aceh,2020 &
\end{tabular}

Berdasarkan tabel 2 di atas peneliti dapat menyimpulkan bahwa pertumbuhan ekonomi di Barat Selatan Aceh sangat fluktuatif setiap tahunnya, di mana pada awal-awal tahun 20132016 pertumbuhan ekonomi sedikit lebih tinggi dibandingkan dengan tahun-tahun setelahnya sehingga penulis menyimpulkan bahwa pertumbuhan ekonomi di Barat Selatan Aceh tidak stabil, yang paling tinggi pertumbuhan ekonomi di tahun 2016 dan yang paling rendah pada tahun 2017.

Sehingga, dengan ditetapkan Undang-undang No. 32 Tahun 2004 maka diharapkan Otonomi Daerah menjadi jembatan terbaik untuk kesejahteraan dan kemakmuran penduduk daerah/lokal melalui berbagai efek multiplier dari desentraliasi. Secara teoritis, kehadiran kedua undang-undang tersebut memberikan pengaruh yang positif terhadap daerah dalam meningkatkan kemampuan daerah untuk berkembang dan menuju kesejahteraan.

\section{Kajian Pustaka}

\section{Desentralisasi Fiskal}

Berdasarkan Undang-undang Nomor 33 tahun 2004, Desentralisasi berarti penyerahan kewewenangan pemerintahan yang diberikan oleh pemerintah pusat kepada pemerintah daerah/daerah otonom untuk mengatur dan mengurus urusan pemerintahannya sendiri dalam sistem Negara Republik Indonesia. Menurut Lituack dalam Zulyanto (2010) ada 3 (tiga) jenis kebijakan Desentralisasi, yaitu:

1. Desentralisasi Politik. Desentralisasi politik merupakan ujung tombak terwujudnya demokratisasi dan peningkatan partisipasi rakyat dalam tatanan pemerintah. Desentralisasi politik yaitu pemberian pelimpahan kewenangan yang lebih besar kepada daerah yang berkaitan dengan aspek pengambilan keputusan, termasuk penetapan standar dan berbagai peraturan.

2. Desentralisasi Fiskal. Desentralisasi fiskal berkaitan dengan keuangan. Yaitu pemberian kewenangan lebih kepada daerah untuk menggali sumber-sumber pendapatan, dan juga berhak untuk menerima tranfer dari pemerintah, dan menentukan belanja rutin daerah maupun investasi daerahnya.

3. Desentralisasi administrasi yaitu pemberian kewenangan, tanggung jawab, dan sumber daya antar berbagai tingkat pemerintahan untuk melaksanakan pelayanan kepada masyarakat

Menurut Khusaini (2006) dalam Zulyanto (2010) terdapat tiga variabel yang sering digunakan sebagai representrasi desentralisasi fiskal yaitu:

1. Desentralisasi Pengeluaran

Variabel ini melihat dari ukuran relatif pengeluaran pemerintah antara pemerintah daerah dengan pemerintah pusat. Desentralisasi pengeluaran diartikan sebagai sebagai rasio antara total pengeluaran pembangunan masing-masing kabupaten/kota terhadap rasio pengeluaran pembangunan nasional (APBN). Melalui variable ini dapat diketahui bentuk posisi pemerintah daerah yang baik dalam melaksanakan investasi sektor publik. Bila hasil dari variable ini didapati hubungan positif antar variabel ini terhadap pertumbuhan ekonomi, maka dapat dikatakan pemerintah lokal dalam posisi yang baik untuk melakukan investasi di sektor publik.

2. Desentralisasi Penerimaan

Variabel ini menjelaskan besaran relatif antara penerimaan pemerintah daerah terhadap penerimaan pemerintah pusat. Variabel ini didapati dari perbadingan rasio total 
penerimaan masing-masing kabupaten/kota (APBD) terhadap total penerimaan pemerintah.

Ada tiga bentuk variasi desentralisasi fiskal dalam kaitannya dengan derajat kemandirian pengambilan keputusan yang dilakukan di daerah yaitu (Santoso dan Rahayu, 2005):

1. Desentralisasi. yaitu pemberian pelimpahan wewenang tanggung jawab ke instansi vertikal di daerah atau pemerintah daerah.

2. Devolusi atau perlimpahan yang berhubungan dengan suatu instansi yang bukan saja implementasi tetapi juga kewenangan untuk memutuskan apa yang perlu dikerjakan berada di daerah.

3. Delegasi yaitu daerah dapat bertindak sebagai perwakilan pemerintah pusat untuk melaksanakan fungsi-fungsi dan situasi tertentu atas nama pemerintah pusat.

Di indonesia ada beberapa prinsip dan tujuan pelaksanaan desentralisasi fiskal antara lain sebagai berikut (Mardiasmo, 2009):

1. Mendukung kesinambungan fiskal dalam kebijakan ekonomi makro.

2. Meningkatkan kualitas pelayanan publik di daerah

3. mengurangi kesenjangan fiskal antara pemerintah pusat dan pemerintah daerah.

4. Meningkatkan efisiensi sumber daya nasional.

\section{Pendapatan Daerah}

Kemandirian suatu daerah dilihat dari daya kemampuannya untuk membiayai kebutuhan daerahnya sendiri. Salah satu sumbernya berasal dari pendapatan Asli Daerah (PAD). Menurut Mardiasmo (2013) PAD adalah penerimaan yang diperoleh oleh daerah bersumber dari pendapatan pajak daerah, restribusi daerah, hasil perusahaan milik daerah, hasil pengelolaan kekayaan daerah yang dipisahkan, dan lain-lain pendapatan asli daerah yang sah. Pendapatan Asli Daerah menunjukkan kemampuan suatu daerah dalam menghimpun, mengalokasikan dan memanfaatkan potensi sumber keuangan daerahnya dalam mendukung pembiayaan penyelenggaraan pemerintah dan pembangunan daerahnya sendiri.

\section{Sistem Hubungan Keuangan Pusat-Daerah}

Berdasarkan UU Nomor 33 Tahun 2004 tentang perimbangan keuangan antara pemerintah pusat dan pemerintah daerah, sumber-sumber keuangan daerah sebagai berikut:

1. sumber-sumber pendanaan keuangan daerah terdiri atas pendapatan asli daerah (PAD), dana perimbangan, pinjaman daerah, dan lain-lain pendapatan yang sah.

2. Pendapatan asli daerah bersumber dari hasil pajak daerah, hasil retribusi daerah, hasil pengelolaan kekayaan daerah yang dipisahkan, dan lain-lain pendapatan asli daerah yang sah.

3. Dana perimbangan merupakan pendanaan daerah yang bersumber dari APBN yang terdiri atas dana bagi hasil (DBH), dana alokasi umun (DAU), dan dana alokasi khusus (DAK). Dana perimbangan tujuan utamanya adalah untuk meningkatkan pelayanan dan kesejahteraan masyarakat agar semakin meningkat dan mengalami perbaikan.

\section{Pertumbuhan Ekonomi}

Pertumbuhan ekonomi menujukkan sejauh mana aktivitas perekonomian akan menghasilkan tambahan pendapatan masyarakat pada suatu periode tertentu (Anitasari dan Soleh, 2015; Rori, 2016). Menurut Sukirno (2006) Pertumbuhan Ekonomi sebagai suatu ukuran kuantitatif yang menggambarkan perkembangan suatu perekonomian dalam suatu tahun tertentu dibandingkan dengan tahun sebelumnya. Menurut Adisasmita (2013) Pertumbuhan Ekonomi merupakan upaya peningkatan kapasitas produksi (input) untuk mencapai penambahan hasil (output), yang diukur menggunakan Produk Domestik Bruto (PDB) dan Produk Domestik Regional Bruto (PDRB) dalam suatu wilayah tertentu. Pertumbuhan ekonomi diartikan sebagai proses kenaikan output perkapita dalam jangka panjang. Pengertian tersebut menekankan pada tiga aspek, yaitu proses, output perkapita, dan jangka panjang. Sebagian ekonom mendenifisikan pertumbuhan ekonomi dalam pengertian yang lebih longgar. kenaikan GDP/GNP tanpa memandang apakah kenaikan itu lebih besar atau lebih kecil dari tingkat pertumbuhan penduduk, atau apakah perubahan struktur ekonomi terjadi atau tidak. 


\section{Kerangka Pemikiran}

Kerangka pemikiran yang tergambar merupakan konsep untuk mengungkap dan menentukan persepsi keterkaitan hubungan antara variabel yang diteliti dan diuraikan dengan kajian teori yang ditulis. Mengacu pada teori-teori yang telah dituliskan di atas maka secara garis besar penulis akan melihat pengaruh desentralisasi fiskal terhadap Pertumbuhan Ekonomi di Barat Selatan Aceh melalui proses analisis data.

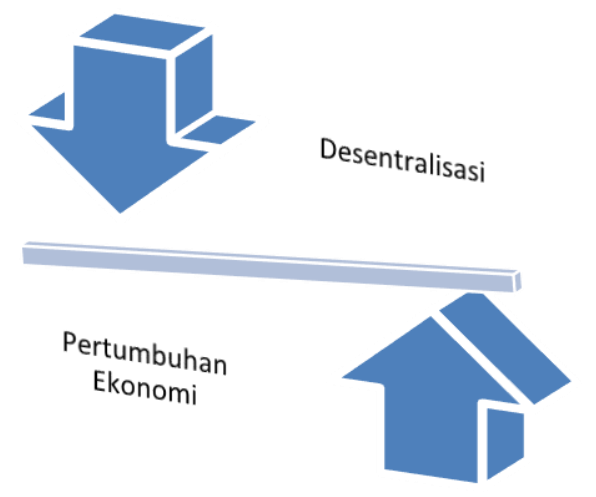

Gambar 1. Kerangka Pemikiran

\section{Penelitian Terdahulu}

Khalid (2015) melakukan penelitian yang berjudul "Pengaruh Desentralisasi Fiskal Terhadap Pertumbuhan Ekonomi di Sulawesi Selatan". Hasil penelitian menunjukkan bahwa variabel desentralisasi fiskal mempunyai pengaruh positif dan signifikan terhadap pertumbuhan ekonomi daerah. Selanjutnya Demora (2016) juga melakukan penelitian untuk menganalisis derajat desentralisasi fiskal, derajat kemandirian, produktivitas belanja daerah dan tingkat keeratan hubungan antara derajat desentralisasi dan kemandirian fiskal dengan produktivitas belanja daerah di Kota Jambi. Data yang digunakan adalah data sekunder berupa runtun waktu (time series) dari tahun 2001-2013 mencakup realisasi Anggaran Pendapatan dan Belanja Daerah (APBD) Kota Jambi dan realisasi Produk Domestik Regional Bruto (PDRB) Kota Jambi. Alat analisis yang digunakan yaitu analisis Derajat Desentralisasi Fiskal (DDF), analisis Derajat Kemandirian Fiskal (DKF), analisis Produktivitas Belanja Daerah (PBD), serta analisis Korelasi Pearson. Hasil analisisnya menunjukkan bahwa derajat desentralisasi fiskal, kemandirian fiskal dan produktivitas belanja daerah di Kota Jambi masih terkategori lemah. Selanjutnya terdapat korelasi positif yang nyata antara derajat desentralisasi dan kemandirian fiskal dengan produktivitas belanja daerah di Kota Jambi.

Qomariyah (2018) juga mengkaji tentang desentralisasi fiskal di kabupaten Jombang. Hasil kajiannya menunjukkan rata-rata derajat desentralisasi fiskal PAD di Kabupaten Jombang sebesar 13,24 \% dengan kriteria kurang, rata-rata derajat desentralisasi fiskal Bagi Hasil Pajak dan Bukan Pajak hanya sebesar 4,92\% dengan kriteria sangat kurang. Sementara derajat desentralisasi fiscal dari sumbangan dan Bantuan sebesar 9,27\% dengan kriteria sangat kurang. Indikasi ini menurutnya menunjukkan tingkat ketergantungan keuangan terhadap pendapatan transfer di Kabupaten Jombang masih relative tinggi.

\section{Metodologi Penelitian}

\section{Ruang Lingkup Penelitian}

Penelitian ini dilaksanakan di 8 (delapan) kabupaten kota terdiri dari Kabupaten Aceh Jaya, Kabupaten Aceh Barat, Kabupaten Nagan Raya, Kabupaten Aceh Barat Daya, Kabupaten Aceh Selatan, Kota Madya Subulussalam, Kabupaten Aceh Singkil dan Kabupaten Sinabang.

\section{Sumber Data}

Dalam penelitian ini data diperoleh dari instansi pemerintah yang terkait seperti kantor BPS Provinsi Aceh dan BPS Kabupaten Kota, kantor DPKKD Provinsi Aceh dan DPKKD Kabupaten Kota, serta data-data yang dipublikasikan melalui karya ilmiah dan literatur yang ada kaitannya dengan permasalahan penulisan penelitian ini.

\section{Analisis Derajat Desentralisasi Fiskal}

Pengukuran derajat desentralisasi fiskal dilakukan dengan menggunakan pendekatan penerimaan, yaitu perbandingan share pendekatan asli daerah terhadap total pendapata daerah dengan rumusnya (Siagian, 2010):

Dimana:

$$
D f i t=\frac{P A D i t}{T P D i t} \times 100 \%
$$

Dfit : Derajat Desentralisasi Fiskal Wilayah Barat Selatan Aceh, pada tahun $t$ 


\section{PADit : Pendapatan Asli Daerah Provinsi $i$, pada tahun $t$ \\ TPDit : Total Pendapatan Daerah Provinsi $i$, pada tahun $t$.}

Bila semakin besar nilai DF, artinya semakin tinggi nilai derajat desentralisasi fiskal di wilayah tersebut, begitu juga sebaliknya semakin kecil nilai DF artinya semakin rendah pula nilai derajat desentralisasi fiskal di wilayah tersebut. Yang menjadi satuan dari derajat desentralisasi fiskal adalah persen.

\section{Analisis Regresi Linier Sederhana}

Analisis regresi dalam penelitian ini menggunakan regresi linier serderhana. Yaitu hanya terdiri atas dua variable; variabel bebas (x) dan variabel terikat $(\mathrm{y})$ :

\section{Dimana:}

$$
Y=a+b X+e
$$

$\begin{array}{ll}\mathrm{y} & =\text { pertumbuhan ekonomi } \\ \mathrm{a} & =\text { nilai konstan (intercept) } \\ \mathrm{b} & =\text { koefisien regresi (slope) } \\ \mathrm{X} & =\text { jumlah desentralisasi fiskal } \\ \mathrm{e} & =\text { faktor penganggu (disturban centrem }\end{array}$

\section{Analisis Korelasi (r)}

Analisis Koefisien Korelasi digunakan untuk mengetahui besaran hubungan antara variabel bebas terhadap variabel terikatnya. Korelasi yang digunakan dalam penelitian ini adalah:

a. Analisa Koefisiaen Korelasi Sederhana

Dalam Regresi Sederhana, jika angka koefisien determinasi tersebut diakarkan maka akan didapat koefisien korelasi ( $r$ ) yang merupakan ukuran hubngan linier antara dua variabel $\mathrm{x}$ dan variabel $\mathrm{y}$. Adapun formula perhitngannya adalah sebagai berikut: (Nacrowi 2006, h.133)

$$
\mathrm{r}=\frac{n \sum X 1 Y 1-\left(\sum X 1\right)\left(\sum Y 1\right)}{\sqrt{\left\{n \sum X 1-\left(\sum X 1\right) 2\right\}\left\{n \sum Y 1-\left(\sum Y 1\right) 2\right\}}}
$$

\section{Dimana:}

$$
\begin{array}{ll}
\mathrm{r} & =\text { koefisien korelasi } \\
\mathrm{n} & =\text { jumlah tahun } \\
\mathrm{y} & =\text { pertumbuhan ekonomi } \\
\mathrm{x} & =\text { jumlah desentralisasi fiskal }
\end{array}
$$

b. Koefisien Determinasi $\left(\mathrm{r}^{2}\right)$

Analisa ini digunakan untuk menyatakan besar kecilnya sumbangan variabel bebas $(\mathrm{X})$ terhadap variabel terikat (Y). Koefisien determinasi $\left(\mathrm{r}^{2}\right)$ merupakan kuadrat dari nilai koefisien korelasi. Rumus Koefisien Determinasi adalah sebagai berikut (Hasan :2002):

$$
K P=r^{2} \times 100 \%
$$

Dimana:

KP : besarnya koefisien penentu (determinasi)

R : koefisien korelasi

\section{Hasil dan Pembahasan}

Pertumbuhan Ekonomi Barat Selatan Aceh Pertumbuhan ekonomi di Barat Selatan Aceh adalah sebagai berikut:

Tabel 3

Pertumbuhan Ekonomi di Barat Selatan Aceh (non migas) Tahun 2001-2019

\begin{tabular}{lllr}
\hline No & Tahun & $\begin{array}{l}\text { Pertumbuhan } \\
(\%)\end{array}$ & Ekonomi \\
\hline 1 & 2001 & & $-0,44$ \\
2 & 2002 & & 7.96 \\
3 & 2003 & & 3.70 \\
4 & 2004 & & 1.76 \\
5 & 2005 & 1.22 \\
6 & 2006 & 7.70 \\
7 & 2007 & 7.23 \\
8 & 2008 & 1.92 \\
9 & 2009 & 3.97 \\
10 & 2010 & & 5.43 \\
11 & 2011 & & 5.69 \\
12 & 2012 & & 6.07 \\
13 & 2013 & & 5.36 \\
14 & 2014 & & 4.02 \\
15 & 2015 & & 4.27 \\
16 & 2016 & & 4.31 \\
17 & 2017 & & 4.23 \\
18 & 2018 & & 5.06 \\
19 & 2019 & & 4.21 \\
\hline Sumber: Aceh dalam angka (Data diolah 2020)
\end{tabular}

Tabel 3 di atas menunjukkan keadaan perekonomian non migas di Aceh menunjukkan terus terjadinya peningkatan dan penurunan selama tahun 2001 sampai dengan 2016 terakhir. Pertumbuhan ekonomi tanpa migas masih menunjukkan angka positif sejak tahun 20022016. Pertumbuhan ini sedikit lebih tinggi bila dibandingkan dengan pertumbuhan ekonomi nasional yang hanya sebesar 6,9 persen. 


\section{Perkembangan Derajat Desentralisasi Fiskal Barat Selatan Aceh}

Berdasarkan data yang telah didapatkan tingkat perkembangan desentralisasi fiskal Barat Selatan Aceh adalah sebagai berikut:

Tabel 4

Perkembangan Derajat Desentralisasi Fiskal Barat Selatan Aceh Tahun 2001 - 2019

\begin{tabular}{cc}
\hline Tahun & $\begin{array}{c}\text { Desentralisasi Fiskal } \\
\mathbf{( \% )}\end{array}$ \\
\hline 2001 & 9,45 \\
2002 & 6,04 \\
2003 & 5,02 \\
2004 & 5,18 \\
2005 & 12,29 \\
2006 & 12,07 \\
2007 & 12,28 \\
2008 & 10,36 \\
2009 & 10,52 \\
2010 & 11,44 \\
2011 & 10,55 \\
2012 & 9,82 \\
2013 & 12,29 \\
2014 & 9,77 \\
2015 & 7,37 \\
2016 & 12,17 \\
2017 & 12,05 \\
2018 & 12,29 \\
2019 & 9,31 \\
\hline Sumber: Aceh dalam angka (Data diolah 2020)
\end{tabular}

Berdasarkan Tabel 4 dapat di jelaskan bahwa perkembangan desentralisasi fiskal Provinsi Aceh dalam kurun waktu tahun 2001 - 2018 terus terjadi peningkatan yang berfluktuasi hal ini disebabkan oleh pertumbuhan ekonomi kurang stabil, selain itu disebabkan dengan pajak kendaraan yang terus terjadi peningkatan setiap tahunnya.

\section{Analisis Hasil Penelitian}

Dari hasil penelitian dapat diketahui persamaan regresi linear sederhana akhir estimasi yaitu sebagai berikut:

$$
\begin{gathered}
Y=a+\beta X+e \\
Y=0.128+0.446
\end{gathered}
$$

Persamaan Regresi linear tersebut di atas dapat dijabarkan sebagai berikut:

a. Konstanta (Pertumbuhan Ekonomi)

Bahwa nilai konstanta bernilai positif yaitu sebesar 0.128. Nilai konstanta ini menggambarkan apabila variabel independen (Desentralisasi Fiskal) sama dengan nol maka tingkat pertumbuhan Ekonomi di Provinsi Aceh akan meningkat sebanyak 12,8 persen.

b. Koefisien Regresi dari variabel Independen (X)

Dari persamaan di atas dapat dilihat bahwa nilai koefisien untuk variabel independen (Desentralisasi Fiskal) di Provinsi Aceh bernilai positif yaitu sebesar 0.446. ini diartikan bahwa setiap kenaikan variabel Pertumbuhan Ekonomi di Provinsi Aceh 1 persen, maka variabel Desentralisasi Fiskal akan meningkat sebesar 44,6 persen.

Berdasarkan hasil regresi linear sederhana diperoleh hasil akhirnya sebagai berikut:

Tabel. 5

Rata-rata Standar Deviasi

\begin{tabular}{cccc}
\hline Variabel & $\begin{array}{c}\text { Rata- } \\
\text { rata }\end{array}$ & $\begin{array}{c}\text { Std. } \\
\text { Deviation }\end{array}$ & $\mathrm{N}$ \\
\hline P.EkonomiY & 4.3856 & 2.38756 & 16 \\
D.FiskalX & 9.5606 & 3.25360 & 16 \\
\hline Sumber: Hasil Regresi (Tahun 2020 diolah)
\end{tabular}

Pada Tabel 5 di atas penulis dapat menjelaskan bahwa rata-rata variabel pertumbuhan ekonomi terhadap Desentralisasi Fiskal adalah 4.3856 dengan standar deviasi 2.38756, Desentralisasi Fiskal terhadap pertumbuhan ekonomi mempunyai rata-rata sebesar 9.5606 dengan standar Deviasi 3.25360, ini berarti pertumbuhan ekonomi bersama-sama mempengaruhi Pertumbuhan Ekonomi di Wilayah Barat Selatan Provinsi Aceh.

\section{Analisis Koefisien Korelasi dan Determinasi}

Tabel 6

Hasil Koefisien Korelasi dan Determinasi

$\begin{array}{lll}\text { Model } & \mathrm{R} \quad \mathrm{R} \text { Square } & \begin{array}{l}\text { Adjusted } \\ \mathrm{R} \text { Square }\end{array}\end{array}$

$\frac{1 \quad 0.613^{\mathrm{a}} \quad 0.369}{\text { Sumber : Hasil Regresi (Tahun } 2020 \text { diolah) }}$

Berdasarkan Tabel 6 di atas peneliti dapat menjelaskan bahwa diperoleh nilai koefisien korelasi variabel $\mathrm{R}=0.613$ atau (61,3 persen). artinya terdapat hubungan yang cukup antara 
variabel independen $(\mathrm{X})$ terhadap dependen $(\mathrm{Y})$ dengan keeratan hubungan 61,3 persen.

\section{Analisis Dampak Pertumbuhan Ekonomi Terhadap Desentralisasi Fiskal di Barat Selatan Aceh}

Dampak dari kebijakan desentralisasi fiskal telah memberikan pertumbuhan ekonomi lebih besar dibandingkan dengan sebelum diberlakukan kebijakan desentralisasi fiskal yaitu sebesar $0,72 \%$ (persen), sehingga kebijakan desentralisasi dianggap penting untuk meningkatkan kemajuan perekonomian daerah. Ada beberapa aspek mengapa kebijakan dari desentralisasi fiskal dianggap penting karena (1) pemerintah dan unsure muspida dan masyarakat di daerah memiliki wewenang yang luas dalam mengatur, mengurus dan menjalankan roda pemerintahan daerahnya sendiri sehingga pembangunannya yang dijalankan sesuai dengan keinginan masyarakat dan lebih tepat sasaran.(2) daerah memiliki peran dalam mengatur keuangan daerahnya sendiri, sehingga bisa menyusun program pembangunan sesuai dengan dana yang tersedia di daerah tersebut. (3) daerah bisa mengembangkan pembangunan berbasis potensi wilayah sesuai dengan keakrifan lokal yang dimiliki, sehingga pembangunan tidak semestinya seragam namun tumbuh secara beragam. (4) kebijakan tidak lagi terpusat pada pemerintah pusat, sehingga pembangunan sangat serat dengan kepentingan kekuasaan yang dipusat dan peran dari perwakilan daerah yang ada di pusat, serta perencanaan pembangunan sering tidak sesuai dengan potensi yang dimiliki oleh daerah masingmasing.

\section{Kesimpulan}

Beberapa saran yang dapat diberikan berdasarkan hasil penelitian yaitu:

1. Pemerintah Kabupaten/Kota Barat Selatan Provinsi Aceh supaya dapat meningkatkan pertumbuhan ekonomi, dan menggali sektor-sektor ekonomi produktif dan potensial yang dapat memberi pengaruh terhadap derajat desentralisasi fiskal di Barat selatan Provinsi Aceh. Cara yang dapat dilakukan adalah dengan cara menciptakan dan mengelola potensi sumber-sumber ekonomi yang efisien. Dikarenakan sektor pertanian masih menjadi primadona di wilayah Barat Selatan Provinsi Aceh sehingga dapat dilakukan upaya peningkatan sarana dan prasarana produksi pertanian, melakukan intensifikasi dan ektensifikasi, perluasan area usaha tani serta memberikan motivasi dan penyuluhan kepada para petani.

2. Bagi penulis selanjutnya untuk dapat mengusahakan menggunakan observasi yang lebih banyak lagi dan beragam agar hasil yang didapati lebih baik lagi

\section{Daftar Pustaka}

Adisasmita, R. (2013). Teori-teori pembangunan ekonomi, pertumbuhan ekonomi dan pertumbuhan wilayah. Yogyakarta: Graha Ilmu.

Anitasari, M., \& Soleh, A. (2015). Pengaruh pengeluaran pemerintah terhadap pertumbuhan ekonomi di Provinsi Bengkulu. EKOMBIS REVIEW: Jurnal Ilmiah Ekonomi dan Bisnis, 3(2).

Badan Pusat Statistik Aceh. (2019). Aceh Dalam Angka. Jakarta: Badan Pusat Statistik.

Bangun, A. (2009). Pengaruh Partisipasi Dalam Penyusunan Anggaran, Kejelasan Sasaran Anggaran dan Struktur Desentralisasi Terhadap Kinerja Manajerial SKPD Dengan Pengawasan Internal Sebagai Variabel Pemoderasi (Studi Kasus Pada Pemerintah Kabupaten Deli Serdang) (Master's thesis).

Demora, V. (2016). Analisis derajat desentralisasi dan kemandirian PAD serta hubungannya dengan produktivitas belanja daerah di Kota Jambi. E-Jurnal Perspektif Ekonomi dan Pembangunan Daerah, 5(1), 13-20.

Khalid, I. (2015). Pengaruh Desentralisasi Fiskal Terhadap Pertumbuhan Ekonomi di Sulawesi Selatan. Jurnal Ekonomi Universitas Muhammadiyah Makassar. 
Kharisma, B. (2013). Desentralisasi Fiskal dan Pertumbuhan Ekonomi: Sebelum dan Sesudah Era Desentralisasi Fiskal di Indonesia. Jurnal Ekonomi \& Studi Pembangunan, 14(2), 101-119.

Kusuma, H. (2016). Desentralisasi Fiskal dan Pertumbuhan Ekonomi di Indonesia. Desentralisasi Fiskal dan Pertumbuhan Ekonomi di Indonesia, 9(1), 1-11.

Mardiasmo. (2009). Kebijakan Desentralisasi Fiskal di Era Reformasi: 2005-2008". Dalam Abimanyu, Anggito dan Megantara, Andie. Era Baru Kebijakan Fiskal: Penerbit Kompas. Jakarta.

Pasaribu, R. F. (2012). Pengaruh desentralisasi fiskal terhadap pertumbuhan ekonomi di provinsi Sumatera Utara (Doctoral dissertation, UNIMED).

Qomariyah, S. N. (2018). Analisis Desentralisasi Fiskal di Kabupaten Jombang. Margin Eco, 2(1), 1-21.

Rori, C. F. (2016). Analisis Pengaruh Pendapatan Asli Daerah (PAD) Terhadap Pertumbuhan Ekonomi di Provinsi Sulawesi Utara Tahun 2001-2013. EFISIENSI, 16(2).

Santosa, P. B., \& Rahayu, R. P. (2005). Analisis Pendapatan Asli Daerah (PAD) dan Faktor-faktor yang mempengaruhinya dalam upaya pelaksanaan otonomi daerah di Kabupaten Kediri. Jurnal Dinamika Pembangunan (JDP), 2(Nomor 1), 9-18.
Sufriadi, D. (2018). Analisis Transformasi Struktural Perekonomian Aceh. Jurnal EKOMBIS, 3(2).

Sukirno, S. (2004). Makroekonomi teori pengantar. Jakarta: PT Raja Grafindo Perkasa.

Sukirno, S. (2006). Ekonomi pembangunan: proses, masalah, dan dasar kebijakan. Kencana (Prenada Media).

SURIANI, N. (2014). Pengaruh Derajat Desentralisasi Fiskal terhadap Pertumbuhan Ekonomi Wilayah di Kabupaten Aceh Selatan (Doctoral dissertation, Universitas Teuku Umar Meulaboh).

Zulyanto, A. (2010). Pengaruh desentralisasi fiskal terhadap pertumbuhan ekonomi di provinsi Bengkulu (Doctoral dissertation, Universitas Diponegoro).

Undang-Undang Republik Indonesia Nomor 11 Tahun 2006. Tentang Pemerintah Aceh.

Undang-Undang Republik Indonesia Nomor 23 Tahun 2014 Tentang Pemerintahan Daerah.

Undang-Undang Republik Indonesia Nomor 32 Tahun 2004. Tentang Pemerintahan Daerah.

Undang-Undang Republik Indonesia Nomor 33 Tahun 2004. Tentang Perimbangan Keuangan Pemerintahan Pusat dan Daerah. 